\title{
Effect of Plant Growth Regulators and their Methods of Application on Growth of kharif Onion (Allium cepa L.) cv Agrifound Dark Red
}

\author{
Bhanuja Dwivedi $^{1 *}$, Garima Diwan ${ }^{2}$ and K. P. Asati ${ }^{1}$ \\ ${ }^{I}$ Department of Horticulture, RVSKVV, College of Indore, MP, India \\ ${ }^{2}$ Department of Horticulture, JNKVV, Jabalpur, MP, India \\ *Corresponding author
}

Keywords

PGRs, DAT,

Growth parameters,

Diameter,

Pseudostem length,

Neck thick

Article Info

Accepted:

18 August 2019

Available Online:

10 September 2019

\section{A B S T R A C T}

An experiment was conducted in field of the nursery, Department of Horticulture, College of Agriculture, Rajmata Vijayaraje Scindia Krishi Vishwa Vidyalaya, Indore during Kharif season, 2017-2018 to see the effect of plant growth regulators and their methods of application on growth of kharif onion (Allium cepa L.) cv. Agrifound Dark Red during 2017 and result have shown significant differences among the treatments. The maximum (48.03) plant height and number of leaves, leaf length (41.53 $\mathrm{cm})$, leaf width $(1.63 \mathrm{~cm})$, leaf area $\left(428.53 \mathrm{~cm}^{2}\right)$, pseudostem length $(9.03$ $\mathrm{cm})$, fresh weight of plant $(57.43 \mathrm{~g})$, dry weight of plant $(12.11 \mathrm{~g})$ were recorded under $\mathrm{T}_{3}\left(\mathrm{GA}_{3} @ 100\right.$ ppm-foliar spray) at 80 days after transplanting (DAT). The maximum polar diameter $(5.77 \mathrm{~cm})$ and equatorial diameter $(5.91 \mathrm{~cm})$ of onion bulb were also exhibited in the treatment $\mathrm{T}_{3}\left(\mathrm{GA}_{3} @ 100 \mathrm{ppm}\right.$-foliar spray) and minimum neck thickness $(1.18 \mathrm{~cm})$ was recorded in treatment $\mathrm{T}_{3}\left(\mathrm{GA}_{3} @ 100 \mathrm{ppm}\right.$-foliar spray).

\section{Introduction}

Onion is one of the most important bulbous vegetable crops grown all over the world. Onion (Allium cepa $\mathrm{L}$.) belongs to the family Amaryllidaceae (Alliaceae) and locally known as Pyaj. It is an old world crop and it was domesticated in Iran and Pakistan i.e. Central Asia. The onion crop is an export oriented crop earning valuable foreign exchange for the country. The demand for onion is worldwide. Onions are found in most of the markets of the world throughout the year and can be grown under wide range of Agro-climatic conditions. Irrespective of price, the demand remains almost constant in the market as it is primarily, used as seasoning for a wide variety of dishes in many homes. The crop export is done mainly to Malaysia, Singapore, Philippines, Indonesia, Gulf countries and Pakistan. Onion accounts for 70 percent of our 
total foreign exchange earnings from the export of fresh vegetables. India is next to China in area and production of onion. Among the different states Maharastra is leading state in terms of area and production. Other major onion states are Gujrat, Karnataka, Odisha, Uttar Pradesh, Andhra Pradesh, Tamil Nadu and Rajasthan. The area of onion is 1270.4 thousand hectare, total production is 21563.9 thousand metric tonnes and productivity is about 17.0metric tonnes per hectare in India (Anonymous, 2017a). The area of onion production in Madhya Pradesh is 118.20 thousand hectares. Total production is 2848.0 thousand metric tonnes and productivity is about 24.09metric tonnes per hectare (Anonymous, 2017b). Onion accounts for 310650.09 lakhs foreign exchange earnings from the export to different countries (Anonymous, 2017c). Government of India has declared onion as an essential commodity.

The pungency in onion is due to sulphurbearing compound which is present in very small quantity (about $0.005 \%$ ) in the form of volatile oil allyl propyl disulphides. The colour of the outer skin of onion bulbs is due to quercetin. It is consumed as a vegetable and condiment. The green leaves, immature and mature bulbs are eaten raw or used in vegetable preparations. It is an indispensable item in every kitchen and used to enhance flavour of different recipes. Onion has many medicinal values and used for preparation of various Homeopathic, Unani and Ayurvedic medicines. Phenolic compounds can offer significant anti-mellitus atherogenic protection by inhibiting the oxidation of low density lipoproteins (LDLs) (Scalbert et al., 2005).

Onions are grown in three seasons, rabi, kharif and late kharif. For maintaining steady supply in the market, kharif crop of onion plays a major role. The production of kharif onion has several advantages i.e. increases total production per annum and fulfils the demand of fresh onion in the market. Kharif onion provides high price as compared to Rabi season onion. The excessive vegetative growth is a problem in kharif onion. The plant height goes up to one meter and neck of the plant become thick, while, the bulb remains small. This is due to poor translocation of assimilates from leaves to bulbs. This translocation of food materials or for altering source to sink relationship is changed by application of plant growth regulators. The positive effect of plant growth regulators on horticultural crops have been shown by many workers (Lal et al., 2013, Lal and Das, 2017, Jain et al., 2017, Tameshwar et al., 2017). The vegetative growth of kharif onion as represented by plant height, number of leaves per plant, fresh and dry weight of plant, increased to optimum level using $\mathrm{GA}_{3}$ and NAA. CCC is very effective in inducing hardening of seedlings and increased growth of root and shoot. TIBA is antiauxins which produced male sterility, and reduce the incidence of Fusarium wilt. Therefore, the present investigation "Effect of plant growth regulators and their application methods on growth of kharif onion (Allium cepa L.) cv. Agrifound Dark Red" was carried out.

\section{Materials and Methods}

An experiment was conducted in field of the nursery, Department of Horticulture, College of Agriculture, Rajmata Vijayaraje Scindia Krishi Vishwa Vidyalaya, Indore during Kharif season, 2017-2018 to see the effect of plant growth regulators and their methods of application on growth of kharif onion (Allium cepa L.) cv. Agrifound Dark Red during 2017 and result have shown significant differences among the treatments. Plant height and number of leaves, leaf length, leaf width, leaf area, pseudostem length, fresh weight of plant, dry weight of plant were recorded on 20, 40, 60 and 80 DAT. Polar and 
equatorial diameter, and neck thickness of bulb was recorded from vernier calliper at harvest. Analysis of variance (ANOVA) was used to test for differences among the treatments.

\section{Results and Discussion}

\section{Plant Height}

The plant height and number of leave per plant increased significantly with the increasing crop growth period. At 20 days after transplantation (DAT), the maximum $(17.67 \mathrm{~cm})$ plant height was recorded in $\mathrm{T}_{3}$ (GA $\mathrm{G}_{3} @ 100$ ppm-foliar spray), followed by $\mathrm{T}_{6}$ (NAA @ 100 ppm-foliar spray) $(16.47 \mathrm{~cm})$, While, the minimum $(13.87 \mathrm{~cm})$ plant height was observed under control. After 40 DAT, the maximum $(23.96 \mathrm{~cm})$ plant height was recorded in $\mathrm{T}_{3}\left(\mathrm{GA}_{3} @ 100 \mathrm{ppm}\right.$-foliar spray), followed by $\mathrm{T}_{6}$ (NAA @ 100ppm-foliar spray) $(23.57 \mathrm{~cm})$, While, the minimum $(21.93 \mathrm{~cm})$ plant height was found in control. In case of 60 DAT, treatment $\mathrm{T}_{3}\left(\mathrm{GA}_{3} @ 100\right.$ ppm-foliar spray), T6 (NAA @ 100 ppm-foliar spray) and $\mathrm{T}_{2}$ (GA 3 @ 100 ppm- seedling dip.) were observed significantly higher $(30.10 \mathrm{~cm})$, $(30.00 \mathrm{~cm})$ and $(29.27 \mathrm{~cm})$ plant height, respectively. However, lowest plant height $(25.70 \mathrm{~cm})$ was recorded under control.

At 80 DAT, significantly maximum (48.03 and $47.93 \mathrm{~cm}$ ) plant height, were observed under treatment $\mathrm{T}_{3}\left(\mathrm{GA}_{3} @ 100 \mathrm{ppm}\right.$-foliar spray) and $\mathrm{T}_{6}$ (NAA @ 100ppm-foliar spray), respectively and which were at par with each other. However, it was recorded lowest (42.07 $\mathrm{cm})$ in control. Similarly, number of leaves per plant of onion increased significantly with the increasing crop growth period and $\mathrm{T}_{3}\left(\mathrm{GA}_{3}\right.$ (a) 100ppm-foliar spray) was found to be the best treatments for maximum number of leave at all stages of observations.

Maximum plant height was observed under treatment $\mathrm{T}_{3}\left(\mathrm{GA}_{3} @\right.$ 100ppm-foliar spray). However, it was recorded lowest in treatment
$\mathrm{T}_{1}$ (control). Plant height is a genetically controlled character but several studies have indicated that the plant height can be either increased or decreased by the application of synthetic plant growth regulators. The increase in plant height by foliar spray of $\mathrm{GA}_{3}$ 100ppm and NAA 100 ppm might be due to rapid increase in cell division and cell elongation in the meristemic region. However significant reduction in these characters can be seen in the growth retardant treatments such as TIBA and cycocel in all the stages of growth. The mechanism of reduction in such traits due to application of growth retardants appears to be due to slowing down of cell division and reduction in cell expansion. It has been suggested that, TIBA and cycocel are anti-gibberellin dwarfing agents, leading to a deficiency of gibberellin in the plant and reduce the growth by blocking the conversion of geranyl pyrophosphate to copalyl pyrophosphate which is the first step of gibberellin synthesis. Thus, reduction in plant height is due to retardation of transverse cell division particularly in cambium which is the zone of meristamatic activity at the base of the internodes. These results are in close conformity with those of Suheela et al., (2005), Islam et al., (2007), Bose et al., (2009), Rashid (2010), Patel et al., (2010a), Patel et al., (2010b), Ouzounidou et al., (2011), Govind et al., (2015), Shashi Kumar and Shashidhar (2016) and Thakur et al., (2018).

Maximum number of leaves plant ${ }^{-1}$ was observed under treatment $\mathrm{T}_{3} \quad\left(\mathrm{GA}_{3}\right.$ @ 100 ppm-foliar spray). In general, leaf is considered as an important functional unit of plant which contributes to yield. Probable reason may be due to the role of these materials in enhancing cell division activity, increasing of proline accumulation of plant and increasing of endogenous phyto hormones i.e. increasing promotion hormones (IAA, $\mathrm{GA}_{3}$ and cytokinins) and reducing ABA content which found that bio-regulators make 
a shift in hormonal balance characterized by increasing in endogenous phyto hormone in plant. Similar results were also obtained by Suheela et al., (2005), Islam et al., (2007), Bose et al., (2009), Rashid (2010), Patel et al., (2010a), Patel et al., (2010b), Govind et al., (2015) and Thakur et al., (2018).

\section{Leaf length $(\mathrm{cm})$}

The leaf length and width of various treatments of onion is given in Table 2 at 20, 40, 60 and 80 days after transplantation. The maximum $(15.60 \mathrm{~cm})$ leaf length was registered in $\mathrm{T}_{3}\left(\mathrm{GA}_{3} @ 100 \mathrm{ppm}\right.$-foliar spray) as compared to control $\left(\mathrm{T}_{1}\right)(11.97 \mathrm{~cm})$ at 20 DAT. At 40 DAT, significantly maximum $(17.56 \mathrm{~cm})$ leaf length was registered in $\mathrm{T}_{3}$ $\left(\mathrm{GA}_{3} @ 100 \mathrm{ppm}\right.$-foliar spray). However, minimum $(15.31 \mathrm{~cm})$ leaf length was observed in treatment $\mathrm{T}_{1}$ (Control). The maximum leaf length $(23.53 \mathrm{~cm}$ and $41.53 \mathrm{~cm})$ was registered in $\mathrm{T}_{3}\left(\mathrm{GA}_{3} @ 100 \mathrm{ppm}\right.$-foliar spray) at 60 DAT and 80 DAT, respectively. However, minimum leaf length $(19.17 \mathrm{~cm}$ and $34.13 \mathrm{~cm}$ ) was observed in control.

\section{Leaf width $(\mathrm{cm})$}

The data clearly indicated that the leaf width of onion plants responded significantly to various treatments of plant growth regulators and methods of application. At 20 days after transplanting, the significantly maximum leaf width $(0.40 \mathrm{~cm})$ was recorded under the treatment $\mathrm{T}_{3}\left(\mathrm{GA}_{3} @\right.$ 100ppm-foliar spray), followed by $\mathrm{T}_{6}$ (NAA @ 100ppm-foliar spray) $(0.37 \mathrm{~cm})$ as compared to other genotypes, while, minimum leaf width $(0.30 \mathrm{~cm})$ was recorded under control.

The maximum leaf width $(1.38$ and $1.48 \mathrm{~cm})$ was recorded under the treatment $\mathrm{T}_{3}\left(\mathrm{GA}_{3} @\right.$ 100ppm-foliar spray) at 40 DAT and 60 DAT, respectively. While, minimum leaf width (1.14 $\mathrm{cm}$ and $1.23 \mathrm{~cm}$ ) was recorded under control at $40 \mathrm{DAT}$ and $60 \mathrm{DAT}$, respectively. At 80 days after transplantation, the significantly maximum $(1.63 \mathrm{~cm})$ leaf width was recorded under the treatment $\mathrm{T}_{3}\left(\mathrm{GA}_{3} @ 100 \mathrm{ppm}\right.$-foliar spray), followed by $\mathrm{T}_{6}$ (NAA @ 100ppmfoliar spray) $(1.60 \mathrm{~cm})$ as compared to other treatments. While, minimum leaf width (1.37 $\mathrm{cm}$ ) was recorded under control. Maximum leaf length and leaf width were recorded in $\mathrm{T}_{3}$ $\left(\mathrm{GA}_{3} @ 100\right.$ ppm-foliar spray).

The increase in plant height by foliar spray of $\mathrm{GA}_{3}$ 100ppm and NAA 100ppm might be due to rapid increase in cell division and cell elongation in the meristemic region. The foliar spray of $\mathrm{GA}_{3}$ and NAA might be responsible for rapid increase in cell division and cell elongation in the meristemic region. These findings are in agreement with the findings of Nandekar and Sawarkar (1992), Patel et al., (2010a) and Patel et al., (2010b) they reported that increase in leaf length with the foliar spray of $\mathrm{GA}_{3}$ and NAA. Singh et al., (1995) and Islam et al., (2007) also supported the leaf length and width increased with these treatments.

\section{Leaf area $\left(\mathrm{cm}^{2}\right)$}

The leaf area and Pseudostem length was recorded and has been presented in table 3 . At 20 days after transplantation, the significantly maximum $(15.49,15.48,14.82,14.27,13.99$ and $13.63 \mathrm{~cm}^{2}$ ) leaf area were recorded in $\mathrm{T}_{3}$ $\left(\mathrm{GA}_{3} @ 100 \mathrm{ppm}\right.$-foliar spray), $\mathrm{T}_{6}$ (NAA @ 100ppm-foliar spray), $\mathrm{T}_{2}\left(\mathrm{GA}_{3} @ 100 \mathrm{ppm}-\right.$ seedling dip.), T 5 (NAA @ 100ppm- seedling dip.), $\mathrm{T}_{4}$ (GA $\mathrm{GA}_{3} @ 100 \mathrm{ppm}$-dropping method) and $\mathrm{T}_{7}$ (NAA @ 100ppm-dropping methods), respectively and which were at par with each other and minimum $\left(10.22 \mathrm{~cm}^{2}\right)$ was observed under control. The maximum leaf area (120.68 $\mathrm{cm}^{2}$ and $186.53 \mathrm{~cm}^{2}$ ) was recorded in treatment $\mathrm{T}_{3}\left(\mathrm{GA}_{3} @ 100 \mathrm{ppm}\right.$-foliar spray) at 40 DAT and 60 DAT, respectively whereas minimum leaf area $\left(88.81 \mathrm{~cm}^{2}\right.$ and 144.99 $\mathrm{cm}^{2}$ ) was recorded under control at 40 DAT and 60 DAT, respectively. 
Table.1 Effect of plant growth regulators and methods of application on plant height $(\mathrm{cm})$ and number of leave per plant at 20, 40, 60 and 80 DAT

\begin{tabular}{|c|c|c|c|c|c|c|c|c|}
\hline \multirow[t]{2}{*}{ Treatments } & \multicolumn{4}{|c|}{ Plant height (cm) } & \multicolumn{4}{|c|}{ Number of leaves per plant } \\
\hline & 20DAT & 40DAT & 60DAT & 80DAT & 20DAT & 40DAT & 60DAT & 80DAT \\
\hline Control & 13.87 & 21.93 & 25.7 & 42.07 & 2.53 & 4.67 & 4.8 & 5.67 \\
\hline GA, @ 100ppm- seedling dip. & 16.2 & 23.37 & 29.27 & 46.16 & 2.93 & 5.2 & 5.63 & 6.47 \\
\hline GA 3 @ 100ppm-foliar spray & 17.67 & 23.96 & 30.10 & 48.03 & 3.13 & 5.33 & 6.00 & 6.47 \\
\hline GA, @100ppm-dropping methods & 15.93 & 23.17 & 29.03 & 45.89 & 2.80 & 5.10 & 5.53 & 6.40 \\
\hline NAA @ 100ppm- seedling dip. & 16.02 & 23.23 & 29.03 & 46.13 & 2.93 & 5.13 & 5.53 & 6.40 \\
\hline NAA@ 100ppm-foliar spray & 16.47 & 23.57 & 30.00 & 47.93 & 3.00 & 5.27 & 5.63 & 6.47 \\
\hline NAA @ 100ppm-dropping methods & 15.60 & 23.00 & 28.67 & 45.80 & 2.80 & 5.07 & 5.47 & 6.30 \\
\hline CCC @ 100ppm-seedling dip. & 15.13 & 22.77 & 28.33 & 44.20 & 2.73 & 4.93 & 5.40 & 6.27 \\
\hline CCC @ 100ppm-foliar spray & 15.27 & 22.83 & 28.47 & 45.73 & 2.80 & 5.03 & 5.43 & 6.30 \\
\hline CCC @ 100ppm-dropping methods & 15.00 & 22.63 & 28.30 & 43.65 & 2.73 & 4.93 & 5.37 & 6.20 \\
\hline TIBA@ 100ppm- seedling dip. & 14.33 & 22.30 & 27.57 & 42.97 & 2.73 & 4.73 & 5.20 & 6.00 \\
\hline TIBA@ 100ppm-foliar spray & 14.50 & 22.40 & 27.73 & 43.31 & 2.73 & 4.87 & 5.33 & 6.13 \\
\hline TIBA@ 100ppm-dropping methods & 14.20 & 22.03 & 25.90 & 42.93 & 2.67 & 4.67 & 5.00 & 6.00 \\
\hline S.Em \pm & 0.33 & 0.24 & 0.35 & 0.33 & 0.08 & 0.06 & 0.05 & 0.07 \\
\hline C.D. $(5 \%)$ & 0.98 & 0.7 & 1.04 & 0.97 & 0.25 & 0.19 & 0.16 & 0.21 \\
\hline
\end{tabular}


Table.2 Effect of plant growth regulators and methods of application on leaf length and width (cm) at 20, 40, 60 and 80 DAT

\begin{tabular}{|c|c|c|c|c|c|c|c|c|}
\hline \multirow[t]{2}{*}{ Treatments } & \multicolumn{4}{|c|}{ Leaf length $(\mathrm{cm})$} & \multicolumn{4}{|c|}{ Leaf width (cm) } \\
\hline & 20DAT & 40DAT & 60DAT & 80DAT & 20DAT & 40DAT & 60DAT & 80DAT \\
\hline Control & 11.97 & 15.31 & 19.17 & 34.13 & 0.3 & 1.14 & 1.23 & 1.37 \\
\hline GA $_{3} @$ 100ppm- seedling dip. & 14.07 & 16.93 & 22.67 & 39.87 & 0.36 & 1.30 & 1.46 & 1.58 \\
\hline $\mathbf{G A}_{3} @$ 100ppm-foliar spray & 15.60 & 17.56 & 23.53 & 41.53 & 0.40 & 1.38 & 1.48 & 1.63 \\
\hline GA 3 @ 100ppm-dropping methods & 14.00 & 16.70 & 22.53 & 39.63 & 0.35 & 1.27 & 1.45 & 1.54 \\
\hline NAA @ 100ppm- seedling dip. & 14.05 & 16.87 & 22.53 & 39.63 & 0.35 & 1.28 & 1.45 & 1.58 \\
\hline NAA@ 100ppm-foliar spray & 14.57 & 16.97 & 23.50 & 41.17 & 0.37 & 1.31 & 1.48 & 1.60 \\
\hline NAA @ 100ppm-dropping methods & 13.9 & 16.57 & 22.30 & 39.39 & 0.35 & 1.27 & 1.41 & 1.52 \\
\hline CCC @ 100ppm- seedling dip. & 13.39 & 16.23 & 21.83 & 37.70 & 0.34 & 1.25 & 1.39 & 1.52 \\
\hline CCC@ 100ppm-foliar spray & 13.83 & 16.37 & 21.97 & 39.27 & 0.34 & 1.25 & 1.40 & 1.52 \\
\hline CCC@100ppm-dropping methods & 12.77 & 16.00 & 21.67 & 36.83 & 0.33 & 1.24 & 1.37 & 1.51 \\
\hline TIBA@ 100ppm-seedling dip. & 12.36 & 15.70 & 20.93 & 36.10 & 0.32 & 1.20 & 1.36 & 1.49 \\
\hline TIBA@100ppm-foliar spray & 12.40 & 15.70 & 21.23 & 36.70 & 0.32 & 1.21 & 1.36 & 1.51 \\
\hline TIBA@ 100ppm-dropping methods & 12.13 & 15.53 & 19.83 & 35.57 & 0.30 & 1.19 & 1.34 & 1.47 \\
\hline S.Em \pm & 0.3 & 0.31 & 0.33 & 0.39 & 0.005 & 0.027 & 0.008 & 0.008 \\
\hline C.D. $(5 \%)$ & 0.89 & 0.93 & 0.98 & 1.15 & 0.01 & 0.08 & 0.02 & 0.02 \\
\hline
\end{tabular}


Table.3 Effect of plant growth regulators and methods of application on leaf area $\left(\mathrm{cm}^{2}\right)$ and pseudostem length $(\mathrm{cm})$ at $20,40,60$ and 80 DAT

\begin{tabular}{|c|c|c|c|c|c|c|c|c|}
\hline \multirow[t]{2}{*}{ Treatments } & \multicolumn{4}{|c|}{ Leaf area $\left(\mathrm{cm}^{2}\right)$} & \multicolumn{4}{|c|}{ Pseudostem length (cm) } \\
\hline & 20DAT & 40DAT & 60DAT & 80DAT & 20DAT & 40DAT & 60DAT & 80DAT \\
\hline Control & 10.22 & 88.81 & 144.99 & 289.17 & 2.07 & 5.90 & 7.27 & 7.47 \\
\hline GA $_{3} @$ 100ppm- seedling dip. & 14.82 & 109.76 & 178.16 & 388.06 & 2.67 & 6.34 & 8.33 & 8.42 \\
\hline GA $_{3} @$ 100ppm-foliar spray & 15.49 & 120.68 & 186.53 & 428.53 & 2.91 & 6.58 & 8.86 & 9.03 \\
\hline GA $_{3} @$ 100ppm-dropping methods & 13.99 & 105.12 & 170.77 & 374.13 & 2.52 & 6.26 & 8.00 & 8.17 \\
\hline NAA @ 100ppm- seedling dip. & 14.27 & 106.92 & 175.48 & 374.16 & 2.52 & 6.30 & 8.10 & 8.23 \\
\hline NAA@ 100ppm-foliar spray & 15.48 & 116.5 & 183.11 & 417.91 & 2.67 & 6.48 & 8.63 & 8.86 \\
\hline NAA@ 100ppm-dropping methods & 13.63 & 103.67 & 167.13 & 369.47 & 2.49 & 6.22 & 7.97 & 8.03 \\
\hline CCC@ 100ppm- seedling dip. & 12.35 & 100.83 & 157.45 & 357.18 & 2.30 & 6.15 & 7.77 & 7.83 \\
\hline CCC@ 100ppm-foliar spray & 12.45 & 101.81 & 164.6 & 367.29 & 2.48 & 6.19 & 7.83 & 7.95 \\
\hline CCC@100ppm-dropping methods & 11.94 & 96.87 & 156.53 & 351.97 & 2.25 & 6.10 & 7.70 & 7.77 \\
\hline TIBA @ 100ppm- seedling dip. & 11.56 & 94.08 & 152.58 & 342.59 & 2.10 & 6.00 & 7.47 & 7.59 \\
\hline TIBA @ 100ppm-foliar spray & 11.56 & 94.19 & 156.22 & 349.07 & 2.15 & 6.07 & 7.63 & 7.70 \\
\hline TIBA@ 100ppm-dropping methods & 10.27 & 91.93 & 150.21 & 329.55 & 2.10 & 5.95 & 7.40 & 7.53 \\
\hline S.Em \pm & 0.67 & 3.87 & 3.3 & 6.5 & 0.05 & 0.01 & 0.05 & 0.05 \\
\hline C.D.5\% level & 1.96 & 11.3 & 9.63 & 18.97 & 0.16 & 0.05 & 0.14 & 0.17 \\
\hline
\end{tabular}


Table.4 Effect of plant growth regulators and methods of application on fresh and dry weight of plant (g) at 20, 40, 60 and 80 DAT

\begin{tabular}{|c|c|c|c|c|c|c|c|c|}
\hline \multirow[t]{2}{*}{ Treatments } & \multicolumn{4}{|c|}{ Fresh weight of plant (g) } & \multicolumn{4}{|c|}{ Dry weight of plant (g) } \\
\hline & 20DAT & 40DAT & 60DAT & 80DAT & 20DAT & 40DAT & 60DAT & 80DAT \\
\hline Control & 9.00 & 24.20 & 36.00 & 41.93 & 0.90 & 3.85 & 6.72 & 8.37 \\
\hline GA 3 @ 100ppm- seedling dip. & 17.00 & 36.30 & 48.43 & 58.53 & 2.90 & 7.89 & 9.78 & 11.88 \\
\hline GA 3 @ 100ppm-foliar spray & 18.20 & 43.27 & 50.07 & 60.27 & 3.60 & 8.98 & 10.32 & 12.11 \\
\hline GA 3 @ 100ppm-dropping methods & 15.60 & 35.27 & 43.97 & 55.73 & 2.60 & 7.39 & 8.96 & 11.63 \\
\hline NAA @ 100ppm- seedling dip. & 16.10 & 35.60 & 47.23 & 57.43 & 2.80 & 7.72 & 9.76 & 11.67 \\
\hline NAA @ 100ppm-foliar spray & 17.40 & 40.30 & 48.53 & 59.00 & 3.50 & 7.99 & 10.07 & 12.01 \\
\hline NAA@ 100ppm-dropping methods & 14.60 & 34.30 & 41.23 & 53.73 & 2.60 & 7.38 & 8.59 & 10.27 \\
\hline CCC @ 100ppm- seedling dip. & 14.30 & 34.00 & 41.10 & 51.23 & 2.50 & 5.25 & 8.41 & 10.10 \\
\hline CCC @ 100ppm-foliar spray & 14.50 & 34.23 & 41.13 & 51.80 & 2.60 & 6.38 & 8.43 & 10.13 \\
\hline CCC@100ppm-dropping methods & 13.90 & 29.07 & 40.77 & 50.70 & 2.30 & 4.83 & 7.40 & 9.78 \\
\hline TIBA@ 100ppm-seedling dip. & 13.50 & 24.67 & 38.83 & 46.33 & 1.80 & 4.44 & 7.00 & 8.85 \\
\hline TIBA @ 100ppm-foliar spray & 13.50 & 28.97 & 39.77 & 48.70 & 2.00 & 4.66 & 7.10 & 9.13 \\
\hline TIBA@ 100ppm-dropping methods & 12.60 & 24.23 & 37.70 & 43.93 & 1.30 & 4.34 & 6.90 & 8.51 \\
\hline S.Em \pm & 2.47 & 2.39 & 2.46 & 1.88 & 0.19 & 0.31 & 0.54 & 0.29 \\
\hline C.D. $(5 \%)$ & 7.23 & 6.98 & 7.18 & 5.51 & 0.56 & 0.92 & 1.60 & 0.85 \\
\hline
\end{tabular}


Table.5 Effect of plant growth regulators and methods of application diameter and neck thickness of bulb

\begin{tabular}{|c|c|c|c|}
\hline \multirow[t]{2}{*}{ Treatments } & \multicolumn{2}{|c|}{ Diameter of bulb (cm) } & \multirow[t]{2}{*}{ Neck thickness of bulb (cm) } \\
\hline & Polar & Equatorial & \\
\hline Control & 5.15 & 5.32 & 1.40 \\
\hline GA3 @ 100ppm- seedling dip. & 5.73 & 5.78 & 1.23 \\
\hline $\mathbf{G A}_{3} @$ 100ppm-foliar spray & 5.77 & 5.91 & 1.18 \\
\hline GA 3 @ 100ppm-dropping methods & 5.61 & 5.71 & 1.25 \\
\hline NAA @ 100ppm-seedling dip. & 5.69 & 5.77 & 1.23 \\
\hline NAA@ 100ppm-foliar spray & 5.74 & 5.88 & 1.23 \\
\hline NAA@ 100ppm-dropping methods & 5.58 & 5.66 & 1.27 \\
\hline CCC @ 100ppm-seedling dip. & 5.51 & 5.62 & 1.29 \\
\hline CCC @ 100ppm-foliar spray & 5.53 & 5.66 & 1.28 \\
\hline CCC @ 100ppm-dropping methods & 5.45 & 5.59 & 1.30 \\
\hline TIBA @ 100ppm- seedling dip. & 5.35 & 5.53 & 1.36 \\
\hline TIBA @ 100ppm-foliar spray & 5.43 & 5.55 & 1.35 \\
\hline TIBA@ 100ppm-dropping methods & 5.20 & 5.40 & 1.38 \\
\hline S.Em \pm & 0.02 & 0.06 & 0.01 \\
\hline C.D. $(5 \%)$ & 0.06 & 0.18 & 0.03 \\
\hline
\end{tabular}


Leaf area fairly gives a good idea of the photosynthetic capacity of the plant. In the present study, it has been observed that the application of plant growth regulators had profound influence on assimilatory surface area. In general, leaf area increased from 20 DAT to 80 DAT. The treatment $\mathrm{T}_{3}\left(\mathrm{GA}_{3}\right.$ ( 100ppm-foliar spray). The results of the present investigation are in accordance with the observations of Ganiger et al., (2002).

\section{Pseudostem length (cm)}

The significantly maximum $(2.91,6.58$ and $8.86 \mathrm{~cm})$ pseudostem length were recorded in treatment $\mathrm{T}_{3}\left(\mathrm{GA}_{3} @ 100 \mathrm{ppm}\right.$-foliar spray), followed by $\mathrm{T}_{6}$ (NAA @ 100ppm-foliar spray) $(2.67,6.48$ and $8.0 \mathrm{~cm})$ at 20, 40 and 60 DAT respectively whereas minimum $(2.07,5.90$ and $7.27 \mathrm{~cm}$ ) was found under control. At 80 DAT, the maximum pseudostem length $(9.03$ $\mathrm{cm})$ were recorded in treatment $\mathrm{T}_{3}\left(\mathrm{GA}_{3} @\right.$ 100 ppm-foliar spray) and minimum $(7.47 \mathrm{~cm})$ in control.

Foliar application of growth regulators recorded the significant difference with respect to pseudostem length of onion. The maximum pseudostem length were recorded in treatment $\mathrm{T}_{3}\left(\mathrm{GA}_{3} @ 100 \mathrm{ppm}\right.$-foliar spray). It may be due to the growth regulators, like $\mathrm{GA}_{3}$ and NAA are involved in cell division, cell expansion, cell elongation and cell differentiation there by leading to enhanced pseudostem length.

\section{Fresh weight of plant (g)}

At 20 DAT, the fresh weight of plants increased significantly by the different treatments at all the growth stages. The significantly maximum $(18.2 \mathrm{~g})$ fresh weight of plant was recorded in the treatment $\mathrm{T}_{3}\left(\mathrm{GA}_{3}\right.$ @ 100ppm-foliar spray), followed by $\mathrm{T}_{6}$ (NAA @ 100ppm-foliar spray) (17.4 g) as compared to other treatments. However, the treatment $\mathrm{T}_{1}$ (Control) was exhibited minimum fresh weight of plant $(9.0 \mathrm{~g})$.

At 40 DAT, the significantly maximum (43.27, 40.30 and 36.30g) fresh weights of plant were recorded in the treatment $\mathrm{T}_{3}\left(\mathrm{GA}_{3}\right.$ @ 100ppm-foliar spray), $\mathrm{T}_{6} \quad$ (NAA @ 100ppm-foliar spray) and $\mathrm{T}_{2} \quad\left(\mathrm{GA}_{3}\right.$ @ 100ppm- seedling dip.), respectively and which were at par with each other. However, the treatment $\mathrm{T}_{1}$ (Control) was exhibited minimum fresh weight of plant $(24.20 \mathrm{~g})$. The significantly maximum $(50.07 \mathrm{~g})$ and $(60.27 \mathrm{~g})$ fresh weights of plant were recorded in treatment $\mathrm{T}_{3}\left(\mathrm{GA}_{3} @\right.$ 100ppm-foliar spray), followed by $\mathrm{T}_{6}$ (NAA @ 100ppm-foliar spray) (48.53 and 59.0g), $\mathrm{T}_{2}\left(\mathrm{GA}_{3} @ 100 \mathrm{ppm}-\right.$ seedling dip.) (48.43 and 58.53g), T5 (NAA @ 100ppm- seedling dip.) (47.23 and 57.43g) and $\mathrm{T}_{4}\left(\mathrm{GA}_{3} @\right.$ 100ppm-dropping method) (43.97 and 55.73g) at 60 and 80 DAT, respectively and which were at par with each other whereas minimum (36.0 and 41.93g at 60 and 80 DAT, respectively) was found under control.

\section{Dry weight of plant (g)}

The average dry weight of plant of different treatments is given in Table 4. Dry weight of plant was recorded at 20,40, 60 and 80 days after transplanting. As regards to $20 \mathrm{DAT}$, the dry weight of plants increased significantly by the different treatments at all the growth stages. The significantly maximum (3.6 and $3.5 \mathrm{~g}$ ) dry weight of plant were recorded in the treatment $\mathrm{T}_{3}\left(\mathrm{GA}_{3} @\right.$ 100ppm-foliar spray) and $\mathrm{T}_{6}$ (NAA @ 100ppm-foliar spray), respectively and which were at par with each other. However, the treatment $\mathrm{T}_{1}$ (control) was exhibited minimum dry weight of plant (0.9 g).

At 40 DAT, the significantly maximum $(8.98 \mathrm{~g})$ dry weight of plant was recorded in the treatment $\mathrm{T}_{3}\left(\mathrm{GA}_{3} @ 100 \mathrm{ppm}\right.$-foliar spray) 
followed by $\mathrm{T}_{6}$ (NAA @ 100ppm-foliar spray) (7.99 g) as compared to other treatments. However, the treatment $\mathrm{T}_{1}$ (Control) was exhibited minimum dry weight of plant (3.85 g). The significantly maximum (10.32 $\mathrm{g}$ and $12.11 \mathrm{~g})$ dry weight of plant were recorded in treatment $\mathrm{T}_{3}\left(\mathrm{GA}_{3} @\right.$ 100ppm-foliar spray), followed by $\mathrm{T}_{6}$ (NAA @ 100ppm-foliar spray) (10.07 and $12.01 \mathrm{~g}), \mathrm{T}_{2}\left(\mathrm{GA}_{3} @ 100 \mathrm{ppm}-\right.$ seedling dip.) (9.78 and $11.88 \mathrm{~g}$ ), T5 (NAA @ 100ppm- seedling dip.) (9.76 and $11.67 \mathrm{~g}$ ) and $\mathrm{T}_{4}$ (GA $\mathrm{GA}_{3} @$ 100ppm-dropping method) (8.96 and $11.63 \mathrm{~g}$ ) at 60 and $80 \mathrm{DAT}$, respectively and which were at par with each other. Therefore, it was observed minimum (6.72 and $8.37 \mathrm{~g}$ at 60 and 80 DAT, respectively) in treatment $\mathrm{T}_{1}$ (control).

Foliar application of growth regulators recorded the significant difference with respect to fresh weight of onion plant. In general, fresh weight of plant increased from 20 DAT to 80 DAT. The significantly maximum fresh weight of plant was recorded in treatment $\mathrm{T}_{3}\left(\mathrm{GA}_{3} @ 100 \mathrm{ppm}\right.$-foliar spray). It may be due to the role of these materials on enhancing cell division activity, increasing of proline accumulation of plant and increasing of endogenous phytohormones i.e. increasing promotion hormones (IAA, $\mathrm{GA}_{3}$ and cytokinins) and reducing ABA content which found that bio-regulators make a shift in hormonal balance characterized by increasing in endogenous phytohormone in plant. Results of the present investigation were also in confirmatory with the findings of Ledesma et al., (2000), Islam et al., (2007) and Ouzounidou et al., (2011).

The amount of total dry matter produced is an indication of the overall efficiency of utilization of resources and better interception of light even if the dry matter production in general is the indication of the efficiency of genotypes. The enhanced productivity of crop through approaches is chiefly achieved by coordinating plant processes to synthesize maximum dry matter and partitioning of the major quantum of this increased dry matter into effective yield contributing factors. Poor translocation of assimilates to the reproductive parts (bulb) is the major constraint in onion.

This can be overcome by the application of growth regulators, which can improve canopy structure and increase the productivity through manipulation of source-sink relationship. In the present study, it was observed that partitioning of total dry matter in leaf and bulb parts varied significantly due to the growth regulator treatments. The amount of dry weight of plant produced is an indication of the overall efficiency of the utilization of resources and better light interception. The data pertaining to total dry weight per plant indicated that, it increased from 20 DAT to 80 DAT. The increase in dry weight of plant up to 80 DAT may be due to higher rate of $\mathrm{CO}_{2}$ fixation and RUBP Carboxylase activity in the early stage of crop growth.

The application of growth regulators significantly improved dry weight of plant and was recorded as maximum in treatment $T_{3}$ $\left(\mathrm{GA}_{3} @ 100 \mathrm{ppm}\right.$-foliar spray). Similarly, Nirmal et al., (1994), Ledesma et al., (2000), Ganiger et al., (2002), Suheela et al., (2005) and Ouzounidou et al., (2011) also reported significant variation in dry weight of plant.

\section{Diameter of bulb (cm)}

The polar diameter of bulb increased significantly due to different treatments. Significantly maximum $(5.77,5.74$ and $5.73 \mathrm{~cm})$ polar diameter of onion bulb were exhibited in the treatment $\mathrm{T}_{3}\left(\mathrm{GA}_{3} @\right.$ 100ppm-foliar spray), T6 (NAA @ 100ppmfoliar spray) and $\mathrm{T}_{2}\left(\mathrm{GA}_{3} @ 100 \mathrm{ppm}\right.$ - seedling dip.), respectively and which were at par with each other. However, the minimum polar diameter of bulb was observed in Control $(5.15 \mathrm{~cm})$. 
The equatorial diameter of bulb increased significantly due to different PGRs. Significantly maximum equatorial diameter of onion bulb $(5.91,5.88,5.78$ and $5.77 \mathrm{~cm})$ were exhibited in the treatment $\mathrm{T}_{3}\left(\mathrm{GA}_{3}\right.$ @ 100ppm-foliar spray), T6 (NAA @ 100ppmfoliar spray), $\mathrm{T}_{2}\left(\mathrm{GA}_{3} @ 100 \mathrm{ppm}\right.$ - seedling dip.) and $\mathrm{T}_{5}$ (NAA @ 100ppm- seedling dip.), respectively and the minimum equatorial diameter of bulb was observed in control (5.32 $\mathrm{cm})$.

It could be noticed that, all treated plants resulted in the highest polar and equatorial diameter of bulb comparing with untreated control. It can be concluded that, spraying onion plant with $\left(\mathrm{GA}_{3} @ 100 \mathrm{ppm}\right.$-foliar spray), (NAA @ 100ppm-foliar spray) and (GA 3 @ 100ppm- seedling dip.) resulted in rapid cell division and elongation leading to bigger bulb formation. Results was also in confirmatory with the findings of Tomar et al., (1988), Shakhda and Gajipara (1998), Tiwari et al., (2001), Islam et al., (2007), Bose et al., (2009), Rashid(2010) and Patel et al., (2010a).

\section{Neck thickness of bulb (cm)}

The neck thickness of bulb was significantly influenced by PGR. The minimum neck thickness $(1.18 \mathrm{~cm})$ was recorded in treatment $\mathrm{T}_{3}\left(\mathrm{GA}_{3} @ 100 \mathrm{ppm}\right.$-foliar spray) as compared to control $(1.40 \mathrm{~cm})$.

The significantly lower neck thickness was noticed in the treatment $\mathrm{GA}_{3} @ 100$ ppm-foliar spray.

The higher neck thickness was noticed in control. The thickness of the stem (neck) is an important parameter for storage of bulb. Hence, more the thickness of the neck more will be the rotting due to more fungous infection. The results of the present investigation are in accordance with the observations of Islam et al., (2007), Bose et al., (2009) and Govind et al., (2015).

Foliar application of $\mathrm{GA}_{3}$ 100ppm $\left(\mathrm{T}_{3}\right)$ was recorded significant maximum growth parameters (plant height, number of leaves plant $^{-1}$, leaf length, leaf width, leaf area, and pseudostem length), fresh and dry weight of plant, polar and equatorial diameter of bulb and neck thickness.

\section{References}

Anonymous. Horticulture statistics at a glance 2017a. Published by Department of Agriculture, Cooperation and Farmers Walfare, Ministry of Agriculture and Farmers Walfare, Govt. of India. pp. 150.

Anonymous. Horticulture statistics at a glance 2017b. Published by Department of Agriculture, Cooperation and Farmers Walfare, Ministry of Agriculture and Farmers Walfare, Govt. of India. pp. 209.

Anonymous. Horticulture statistics at a glance 2017c. Published by Department of Agriculture, Cooperation and Farmers Walfare, Ministry of Agriculture and Farmers Walfare, Govt. of India. pp. 407

Bose, U.S., Bisen, A., Sharma, R. K. and Dongre, R., 2009. Effect of micro nutrients along with growth regulator on growth and yield of onion. International Journal of Applied Agricultural Research. 4 (3): 267-271.

Ganiger, T.S., Kareekatti, S.R., Patil, B.C., 2002. Effect of plant growth regulators on growth and yield in cowpea. Karnataka Journal of Agricultural Sciences.15 (4): 701-704.

Govind, S. Maji, Kumawat, R., Pal, A., Kumar, S. and Saha, S., 2015. Improvement of growth, yield and quality of garlic (Allium sativum L.) CV. G-282 through a novel approach. 
Bio Science. 10 (1): 23-27.

Islam, M.S., Islam, M.O., Alam, M.N., Ali, M.K. and Rahman, M.A. 2007. Effect of Plant growth regulator on growth, yield and yield components of onion. Asian Journal of Plant Sciences. 6: 849-853.

Jain, S., Sharma, T.R., Lal, N., Rangare, N.R. and Kumar, B. 2017. Effect of $\mathrm{GA}_{3}$ and growing media on seed germination and growth of Custard apple (Annonas quamosa L.). International Journal of Chemical Studies. 5(4): 699-707.

Lal, N. and Das, R.P. 2017. Effect of plant growth regulators on yield and quality of guava (Psidium guajava L.) cv. Allahabad Safeda. Int.J.Curr.Microbiol.App.Sci., $\quad 6(5)$ : 857-863.

Lal, N., Das, R.P. and Verma, L.R. 2013. Effect of plant growth regulators on flowering and fruit growth of guava (Psidium guajava L) cv. Allahabad Safeda. Asian Journal of Horticulture. 8(1):54-56.

Ledesma, A., Argiiello, J.A., Nunez, S.B. and Nieto, N. 2000. Effect of $\mathrm{GA}_{3}, \mathrm{CCC}$ and nitrogen fertilization on bulbing in garlic (Allium sativum L.) cv Rosado Paraguayo Alpa-Suquia, derived from seed cloves stored at low temperatures. The $3^{\text {rd }}$ International Symposium on Edible Aluaceae. The University of Georgia, October 29 through November 3, 2000. pp 12.

Nandekar, D.N. and Sawarkar, S.D. 1992. Note on effect of growth regulators on growth, yield and quality of Kharif onion. Indian J. Horti. 49 (3): 267-269.

Nirmal, S.V., Deore, B.P. and Patil, R.C. 1994. Effect of growth substances on yield and yield contributing traits in onion. J. Maharashtra Agril. Univ. 19 (1): 136-137.

Ouzounidou, G., Giannakoula, A., Asfi, M. and Ilias, I. 2011. Differential responses of onion and garlic against plant growth regulators. Pak. J. Bot. 43 (4): 2051-2057.

Patel, M.J., and Chavda, J.C. 2010a. Influence of plant growth regulators and their application methods on yield and quality of onion (Allium cepa L.). Asian Journal of Horticulture. 5 (2): 263-265.

Patel, M.J., Patel, H.C. and Chavda, J.C. 2010b. Effect of plant growth regulators and their application methods on growth and yield of onion (Allium cepa L.) cv. gujarat white onion-1, Adv. Res. J. Crop Improv. 1 (2) : 85-87.

Rashid, M.H.A. 2010. Effect of sulphur and $\mathrm{GA}_{3}$ on the growth and yield of onion. Progress. Agric. 21(1\& 2): 57 - 63.

Scalbert, A., Manach, C., Morand, C., Remesy, C. and Jimenez, L. 2005. Dietary polyphenols and the prevention of diseases. Critical Reviews in Food Science and Nutrition. 45: 287-306.

Shakhda, V.P. and Gajipara, N.N. 1998. A note on influence of IAA IBA and $\mathrm{GA}_{3}$ on growth and yield of onion (Allium cepa L.). Vegetable Science. 25 (2): 185- 186.

ShashiKumar, H.M. and Shashidhar, T.R. 2016. Effect of foliar application of growth regulators and bio stimulants on growth and yield of onion Var. Bhima Shakti. J. Farm Sci. 29 (1): 5052

Singh, S., Singh, K., Singh, S.P. and Singh, S. 1995. Effect of hormones on growth and yield characters of seed crop of kharif onion (Allium cepa L.). Indian Jour. of plant physiology. 38 (3): 193196.

Suheela, T., Ravisankar, C. and Rao, B.V. 2005. Effect of growth regulator and methods of application on growth and 
yield of onion cv. N- 53. Journal of ANGRAU. 33 (4): 110-113.

Tameshwar, Prasad, V.M. and Lal, N. 2017. Effect of plant growth regulators on gladiolus cv. Jester. Trends in Biosciences. 10 (20): 3982-3985.

Thakur, O., Kumar, V. And Singh, J. 2018. Pruning and gibberellic acid on the growth and yield attributes of onion (Allium cepa L.) var Agrifond Light Red. Int. J. Curr. Microbiol. App. Sci. 7 (1): 976-981.
Tiwari, N., Singh, P., Verma, L., Katiyar, P.K. and Vaish, C.P. 2001. Effect of pre sowing seed treatment on germination, growth and yield of onion (Allium cepa L.). Seed Research. 29 (2): 238-239.

Tomar, S.P.S, Singh, T.P. and Tomar, G.S. 1988. Effect of planting date and hormone on onion (Allium cepa L.) yield. Indian J. Agril. Sci. 58 (2): 136138.

\section{How to cite this article:}

Bhanuja Dwivedi, Garima Diwan and Asati K. P. 2019. Effect of Plant Growth Regulators and their Methods of Application on Growth of kharif Onion (Allium cepa L.) cv Agrifound Dark Red. Int.J.Curr.Microbiol.App.Sci. 8(09): 1597-1610.

doi: https://doi.org/10.20546/ijcmas.2019.809.183 